\title{
Factors Associated with Substance Use Disorder among Adolescents Age Group: An Integrative Review
}

\author{
Malek M. Khalil'1, Ayman M. Hamdan-Mansour² \\ ${ }^{1}$ Faculty of Nursing, Zarqa University, Zarqa, Jordan \\ ${ }^{2}$ Psychiatric and Mental Health Nursing, Department of Community Health Nursing, School of Nursing, \\ The University of Jordan, Zarqa, Jordan \\ Email: tarifi_11684@yahoo.com
}

How to cite this paper: Khalil, M.M. and Hamdan-Mansour, A.M. (2019) Factors Associated with Substance Use Disorder among Adolescents Age Group: An Integrative Review. Open Journal of Nursing, 9 , 998-1011.

https://doi.org/10.4236/ojn.2019.99074

Received: July 15, 2019

Accepted: September 16, 2019

Published: September 19, 2019

Copyright $\odot 2019$ by author(s) and Scientific Research Publishing Inc. This work is licensed under the Creative Commons Attribution International License (CC BY 4.0).

http://creativecommons.org/licenses/by/4.0/

\begin{abstract}
Aim: Reviewing the existed literature that addresses the factors influencing adolescent's substance use disorder. Background: Substance use disorder among adolescents considered a major problem worldwide that affects adolescents wellbeing and destroys their functionality socially, physically and psychologically. Data Sources: A review of relevant literature uses electronic databases including EBSCO, MEDLINE, CINAHL, and PubMed. Methods: Using an integrative method, peer-reviewed research and discussion papers published between 2011 and 2019 and listed in the CINAHL, SCOPUS, Science Direct, PubMed and Google Scholar databases were reviewed. Findings: A final review of 9 studies that used quantitative and qualitative research methods to study many factors was related to the substance use disorder. Themes were: Influence of psychological factors on adolescents. Influence of socio-cultural factors on adolescents, the influence of biological factors on adolescents and the influence of environmental factors on adolescents. Conclusions: Reviewed articles revealed that many psychological, biological, socio-cultural, and environmental factors that increase adolescents risk having substance use disorder. For example, stressful life events during adolescents like loss of someone increase the risk to take illicit substances in order to forget painful memory; personal tendency like curiosity and experimentation, increase the risk to have risk health behaviors like substance use disorder. Furthermore, adolescence is a critical period that youth need more supervision and health education to protect them from Substance use disorder.
\end{abstract}

\section{Keywords}

Substance Use Disorder, Adolescents, Influencing Factors, Causes 


\section{Introduction}

Substance Use Disorder (SUD) is one of the difficult problems and considered a global health problem that increases the burden on families and governments, more than 600 billion dollars dispensed on substance use yearly in USA [1] [2]. SUD is a self-destructive behavior that leads to a high incidence of early death; around 70,200 Americans died from drugs overdose in 2017 which increased every year [3]. However, a definite treatment for SUD not available yet [4]. There are a lot of therapeutic programs for rehabilitation only, but the relapse rate is still high [1]. Substance use disorder was generally defined as a misuse of illicit drugs or psychoactive substances like marijuana, hashish, and amphetamines which have a negative impact on individuals and those individuals have exacerbated desire to repeat take these substances [4] [5]. Many types of these substances are available now almost around ten separate classes of drugs: alcohol, caffeine, cannabis, hallucinogens, inhalants, opioids, sedatives, hypnotics or anxiolytics, stimulants, and tobacco use [5].

Substance use disorder is more common among adolescents, adolescent is a dynamic developmental period started from puberty until reach to social independence and ranged from 10 to 18 years and also from 18 - 21 years with variations according to some cultures and societies [6]. Physical, emotional, social and psychological changes occur during the adolescent stage. This changes make adolescents more vulnerable to health risk behaviors such as SUD [6], for examples, adolescents like to separate from parents, like to take independent decision and responsibility, like to imitate and take adult roles and like to confirm their identity, for that reason, adolescents are risker than other ages to consume psychoactive substances or illegal drugs [6]. On the other hand, adolescents who do not have such protective factors are more likely to have health risk behaviors like substance use disorder. Therefore, the purpose of this review was to identify the factors that influence adolescents to have substance use disorder. Influencing factors: Factors that motivate the adolescent to consume harmful substances like marijuana and cocaine [4]. Causes of substance use disorder: Factors that inspire adolescents to have substance use disorder like family problems and loss of parents [4].

\subsection{Adolescent Development}

Adolescent's developmental period contains three major phases of development which are cognitive, psychosocial, and psychological development phase [7] [8]. Cognitive development phase: is a process of change thinking from childhood like thinking to adulthood like thinking, during this period of change the adolescents become able to use logic thinking, to think abstractly; and convert thinking from direct (concrete) to abstract thinking (imagine things), those changes will motivate adolescents to love and search in spirituality. Adolescents feel with satisfaction when they do health risk behaviors like substance use despite the negative consequences of use because they think through their emo- 
tions and difficult to understand the relationship between cause and effect of substances. Furthermore, adolescent's ability to do meta-cognition developed; it means that they have the ability to think about thinking [7] [9]. Psychosocial development phase: adolescents like to act as adults during the early adolescent period between 12 and 14 years of age. Adolescents like to do adult roles being independent and ignore advice from parents, being neat and in a good appearance in front of others [7] [10]. Adolescents like to initiate love or emotional relationship with the other sex and consider him/her as a partner during the middle adolescent period (15 - 17 years of age). Additionally, adolescents do permanent relationship during the last stage of adolescent (18 - 21 years of age) [7] [11].

Furthermore, Erikson (1950) named the period between 13 and 19 years of age with "identify versus role confusion", in this transitional period of time, adolescents like to do adult roles in order to affirm their identity [12]. Therefore, adolescents are confused about which act fit their identity, so they are at risk to do maladaptive behaviors like substance use disorder. Psychological development phase: Brain development has an integral part in developing SUD, areas in the brain which are responsible for decision making and behavioral impulses which myelinated late stimulate impulsiveness in adolescents which can result in health risk behaviors like substance use disorder [13].

\subsection{Study Purpose}

The purpose of this integrative literature review is to review the existed literature that addresses the factors influencing adolescent's substance use disorder.

\section{Materials and Methods}

\subsection{Search Strategy}

The search process targeted articles published in peer-reviewed journal that is relevant to identified study key words. The search was conducted using the following online bibliographic databases: PubMed, ProQuest, Medline, Google Scholar, SAGE Journals, Wiley on Line Library, Science Direct, EBSCO host, Ovid journals, and Cochrane for systematic review articles The keywords which have been used were "substance use disorder", "adolescents", "influencing factors", "causes". Boolean operators (AND, OR) have been applied separately and in combination with the keywords to expand, combine, or exclude keywords in a search to narrow down the results. The reviewed studies focused on the risk factors and associated factors of substance use disorder among adolescents internationally, which used quantitative and qualitative approaches in order to understand deeply which factors stimulate adolescents to consume illegal drugs.

\subsection{Inclusion Criteria}

The relevant articles in this integrative review were limited to: written in English language, published in peer-reviewed nursing and non-nursing journals, the pe- 
riod of publication from 2010 onward, Abstracts, conference papers, unpublished reports, opinion papers were excluded to be included from this review.

\subsection{Search Strategy Outcomes}

A librarian experienced in systematic searches of academic databases assisted the researchers in developing and performing the search strategy. The primary search in selected databases retrieved 753 articles, and articles through other resources. After removing duplicates 426 unique articles were identified. After screening the abstracts, 129 articles were excluded because they did not meet the inclusion criteria. From the reviewed abstracts, 48 articles met our search criteria and were reviewed in full. Of these, 9 final articles were selected. Afterward, the selected articles were assessed for eligibility based on their full-text (Figure 1).

\section{Results}

Nine relevant articles have been reviewed and the following data have been extracted: study purpose, design, sample, and findings. The authors compared the articles; findings interpreted to extract themes and grouped them based on their similarities. On the whole, all of the nine articles published between 2010 and 2019 are reviewed (three qualitative studies, four cross-sectional quantitative studies, and two correlation quantitative studies); all articles presented in Appendix.

In order to address the purpose of this integrative review, the findings (the risk factors of substance use disorder) were categorized into common themes, a

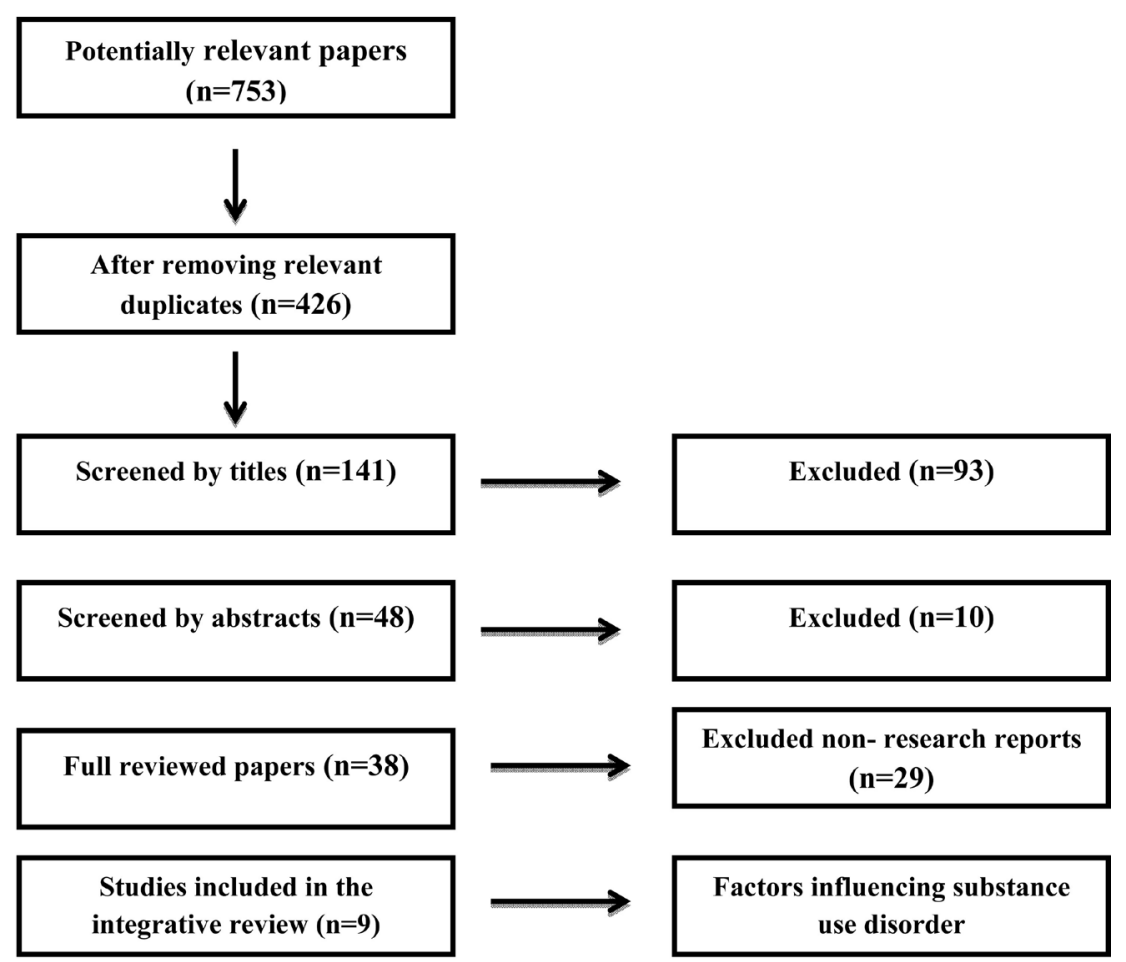

Figure 1. Search strategy outcomes. 
color-coding method used to highlight the similarities of themes in this literature. The following four main themes were emerged: 1) influence of psychological factors on adolescents 2) influence of socio-cultural factors on adolescents 3) influence of biological factors on adolescents and 4) influence of environmental factors on adolescents. The reason for emerging these themes identifies factors that influence adolescents to have SUD.

\subsection{Theme One: Influence of Psychological Factors on Adolescents}

A study conducted by Lalayants \& Prince [14]. Child neglect and the onset of substance use disorders among child welfare. This study involved adolescents to clarify the relationship between child abuse and substance dependence versus child neglect and substance dependence. Data set used by the researchers was from (The National Survey of Child and Adolescent Well Being II [15], it is a longitudinal data set which represents 5872 children and young people aged (0 18) from 83 counties in New York. The data set contains much information about the social relationship, services needs, mental health and academic achievement for children and their caregivers and other important information. The results of the study showed that maltreatment of a child and youth increases the risk of SUD, child and youth negligence considered one of the most common maltreatment types which increase the likelihood to emerging of SUD. Other types of child maltreatment like psychological aggression, physical assault, and sexual abuse can lead to SUD in the presence of negligence. Child and youth negligence is the lack of supervision and monitoring by parents or caregivers [14]. Youth delinquency and health risk behaviors can be the result of child negligence [14]. Many adolescents may go to take illegal drugs in order to forget painful memories, self-blame, and depression [14].

Moreover, a cross-sectional quantitative study conducted by Ali, Dean Jr. \& Hedden [16] to exam if parents with comorbid mental illness and substance use disorder have effects on their adolescents and is more risky to have SUD. Data set taken from the national survey on drug use and health (NSDUH) [16], this data collected annually using face to face interviews from parents and their children for the purpose of detecting the prevalence and correlates of substance use disorders among civilians in the United States ages 12 years and above. The data collected from 67,500 participants who are completed the interview. The parent-child data collected over six years from 2008 to 2013 to examine the relationship between adolescent with SUD and parent with any mental disease or SUD separately from mothers and fathers. Analysis for this study conducted from 18,500 adolescents aged 12 to 17 whose mother $(n=9300)$ or father $(n=$ $5300)$ are staying in the home and completed the interview. The multivariate regression analysis has conducted that show the parents with any mental illness and SUD influence their adolescents to have SUD, but mothers have more influence than fathers. However, according to the analysis, mothers with both any mental illness and SUD have about five times the odds ( $\mathrm{OR}=4.80,95 \% \mathrm{CI}=$ 2.66 - 8.68) of having SUD compared with other mothers having only either 
mental illness or SUD. The mothers with only any mental illness or SUD are not statistically significant to influence the adolescents to get SUD, while mothers with comorbid any mental illness and SUD are statistically significant (Köck \& Walter, 2018). The limitation of this study was not reporting if adolescents' behavior can influence on parents behaviors or not, also, the study did not report parents' influences on gender, and the effect if more either on female adolescents or male adolescents.

\subsection{Theme Two: Influence of Socio-Cultural Factors on Adolescents}

A cross-sectional study conducted in the correctional institute in Jimma by Yitayih et al. [17] on prisoners to study the prevalence of SUD among prisoners in Jimma and their associated factors. The participants were 336 (66.6\% aged less than 30 and $33.4 \%$ with age more than 30 ). The findings of this study showed that the prevalence of SUD was $55.9 \%$, the prevalence was $36.2 \%$ among alcohol use disorder, $19.8 \%$ among nicotine dependence, and 3.6\% among cannabis use disorder. Additionally, the study reported that people who lack social support are more likely to have SUD, the people live in urban areas are more likely to have SUD than people live in rural areas, the people with psychopathy are more likely to have SUD than people without psychopathy, and lastly people who lack supervision are more likely to have SUD.

An exploratory quantitative correlational study utilizing longitudinal analysis method conducted by Yoon et al. [18] which about Vulnerability or resilience to early substance use among adolescents at risk: the roles of maltreatment and father involvement. In this study, the sample size was a secondary data analysis with of 685 adolescents at risk to develop substance use which drawn from the longitudinal studies of child abuse and neglect (LONGSCAN). This sample size was enough to eliminate the sampling error and being representative of the target population. The study aimed to examine the type of maltreatment in early childhood within 0 - 5 years, in mid-late childhood within 6 - 12 years, and its effect on early substance use among adolescents with a high risk of maltreatment, and examine the role of father involvement during childhood. The data was collected during ages 4, 6, 8, 12, 14, 16 and 18 in the period (from July 1991 to January 2012), using Interviews from different age group, but in this study, the data used was data collected on ages 12 and 14 . The data was restricted to include only the adolescents who have a father because the aim of the study is to examine the role of father involvement in decreasing the likelihood of adolescents to be a substance user. The result of the study showed that there is a positive relationship between father involvement and substance use; especially when there is a lack of connectedness between father and children in the early childhood that will increase the adolescents' risk to substance use. Additionally, the study showed that physical abuse during early childhood period ( 0 - 5 years of age) and mid-late childhood ( 6 - 12 years of age) increased the tendency of adolescents for substance use than other children who didn't experience physical abuse. The results discussed that white adolescents are at high risk to have sub- 
stance use two times than black adolescents. The mothers with high education degree are less likely to have adolescents with substances use, while mothers without high education degree or illiterate are more likely to have adolescents with substance use. Furthermore, this study did not assess many maltreatment characteristics like severity, frequency and age onset of maltreatment. Therefore, the study cannot be generalized to all population because some confounding variables cannot be controlled. One of these variables was a participant who has a family with SUD.

A qualitative retrospective content analysis conducted by Davis, J et al. [19] which about extending poly-victimization theory: differential effects of adolescents' experiences of victimization on substance use disorder diagnosis upon treatment entry. The study aim was to assess the relationship between adolescent's victimization and substance use disorder. The study sample was 20,093 adolescents who entered a project for substance use treatment. The authors used latent class and multi-class analysis to discover if the adolescent victimization is a risk factor for substance use disorder. The data was taken from the Chestnut Health System in the United States who used the GAIN-1 (Global Appraisal of the individual needs coordinating center) assessment tool which consisted from a structured interview with more than one hundred scales. The data were collected by the treatment agency staff from 2002 to 2013 after they received a special training by specialties for being certified to conduct the interviews. The participants recruited by different sources: Juvenile justice system, school referral, parents and self-referral. The distribution of sample was a male $(\mathrm{n}=14,811)$ with different races white $(n=7261)$, Hispanic $(n=6014)$, African American $(n=3089)$ and other races $(n=634)$. About $33 \%$ of the sample has met the criteria for substance abuse and about $5.5 \%$ have met the criteria for substance dependence. The results of the analysis using latent class analysis (LCA) in Mplus version 8 were reported that nearly a third of the sample exposed to victimization many times and for a long duration of time and the assaulter was a family member or a trusted one. The adolescents' who have exposed to victimization more than two times are more risk to have health risk behaviors such as substance use disorder or psychiatric disorders. Moreover, the victimization has different types like physical abuse, sexual abuse, and negative social reaction, perceived life threat, witnessing violence, emotional abuse, and trusted perpetrator. The study results showed that adolescents who experienced poly victimization and high harmful trauma such as; emotional, physical and sexual abuse and abused by family member or a trusted one are the riskier to have substance use disorder compared to low all class. The study used a large sample size which considered a strength point, the analytical process takes into consideration multiple aspects of victimization, the study cannot be generalized because it conducted in one country in the United States, the study just interested with characteristics of victimization and did not report other types of trauma such as; natural disasters, wars, car accidents, and domestic violence and also the research authors did not detect the frequency of associated trauma characteristics. 


\subsection{Theme Three: Influence of Biological Factors on Adolescents}

A qualitative study was conducted by Berlowitz et al. [1] to investigate alternative treatments and conceptions from traditional Amazonian medicine adapted to SUD. The data was collected through semi-structured interviews with 13 practicing experts. The experts reported that Stressful life events such as; sexual abuse, childhood abuse, and disappointment in a job or a relationship were considered the factors that contribute to SUD. Additionally, the lack of love, caring from family or parents can play an integral role to cause adolescents having SUD. The personal tendencies such as curiosity, low self-esteem, experimentation, and being weak were influenced the adolescent to be a substance user. The emotional changes or mood fluctuations like anger, anxiety, grief, feeling with loneliness, and lack of attachment with family was also influenced adolescents to be a substance user.

\subsection{Theme Four: Influence of Environmental Factors on Adolescents}

A cross-sectional study conducted by Iranpour et al. [20] which about an applying of the social developmental model. The aim of this study was to develop risk and protective factors of substance use scale to determine risk and protective factors influencing substance use among adolescents. The study participants were 325 male students from $9^{\text {th }}$ and $10^{\text {th }}$ grade ( $14-18$ years old) at public high schools in Kerman, Iran were selected through multistage cluster sampling. The study results reported that both smoking and alcohol are considered a gateway for SUD. Also, there are many factors that increase the tendency to consume illicit drugs and these factors includes wrong beliefs and perception about the effects of illicit substances, and they think that hookah and alcohol do not have negative consequences like other illicit substances, lack of bonding and attachments with parents and lack of family monitoring increase the tendency of adolescents to have SUD, inappropriate relationship between family and adolescents increase the tendency of adolescents to have SUD.

A cross-sectional study conducted by Mason et al. [21] is a bi-national study. The aim of this study aimed to examine the relationship between early age alcohol use and the risk of adolescent alcohol problems. The study sample was 1945 participants (49\% males and 51\% females) who recruited from two states in the US; Washington and Victoria by International Youth Developmental Study (IYDS) [21]. The sample selection was from Victoria 54 classes in 54 schools. Washington 51 classes in 51 schools. The study results reported that poor self-regulation and peer aberration increase the tendency of adolescents for alcohol abuse. Moreover, this is consistent with other studies that alcohol use considered a gate way for substance use disorder [21].

Furthermore, according to DSM-5 criteria [5], the individual who takes substances can be diagnosed with substance use disorder if he/she has two or more of the eleven listed criteria or symptoms. This study used self reported ques- 
tionnaire to collect data which mean that may be there is a risk for bias. The sample was from to states in the USA which mean that it is not representative and cannot be generalized to all states.

Substance use disorder criteria in DSM-5 [5] [22] includes the following: Consuming large amounts of substances more than expected or planned, failed to stop taking substances, Long period of time dispended on consuming substances, Consuming substances lead to inability to fill the ideal roles (work, school or home), Intense desire for the substance, Continuous taking the substances despite it is consequences on health and mental functioning, Continue to take the substance despite its negative effects on the relationship (loss of friendship, loss of partner), Use the substance during dangerous situations such as driving or duty at work, Disregard to participate in enjoying activities due to substance use, Take more amounts of substances over time to get the same preceded desired effect and finally withdrawal symptoms occur if the substance user stops taking substances. These withdrawal symptoms like nausea, irritability, fatigue, vomiting, hand tremors and seizure.

A qualitative study conducted by El Kazdouh, El-Ammari, Bouftini, El Fakir, \& El Achhab [23] in Morocco. The purpose of this study was to deeply understand factors that influence morocco adolescents to consume illegal substances through exploring the perceptions of students, their parents, and teachers. The study participants were 8 groups of adolescents ( 28 boys and 28 girls) with age from 14 - 16 years, 5 groups of parents ( 5 females and 21 males), and 4 groups of teachers (13 males and 5 females). The results of this study showed that there are six emerging themes in which considered the factors that influence adolescents to consume substances; the first one was the perceived benefits from the substance use; adolescents believe that they can feel with pleasure and forget painful emotions through consuming substances. The second one was lack of awareness; which means they have a lack of knowledge about the side effects and complications of substance use. The third one was lack parental supervising; which mean that parents forget to monitor their children, they do not have time or they are busy all the time. The forth one was peer pressure and family influence; this means that if the family or some of the family members are abuse. The fifth one was psychological problems like personality disorders and another theme was low academic achievement and absenteeism; adolescents who absence from the school they are at high risk to make friendship with gangs. Moreover, this study conducted in two schools in urban areas in Morocco, which means that the results of the risk factors for substance use in adolescents cannot generalized in other countries.

\section{Discussion}

The aim of this literature review was to identify factors that influence adolescents to have substance use disorder internationally in which four themes emerged. The psychological factors showed increased the risk of having SUD. 
Therefore, the adolescents with previous stressful life events, painful trauma, painful memories of self-blame and depression at high risk to have SUD [1] [14]. The adolescents with mental illness like psychopath and personality disorder are at high risk to consume illicit substances and have SUD [14] [23]. The adolescents who experienced different types of abuse during childhood are at high risk to have SUD [18]. The mother has SUD it is estimated for her adolescents to have SUD and if the mother has co-morbidities of any mental illness with SUD is five times high risk to have adolescents with SUD than mothers who only have SUD [16].

The socio-cultural factors such as; lack of monitoring by parents, lack of social support, sexual abuse, lack of bonding, and victimization by family increase the risk for adolescents to have SUD [17] [18]. The biological factors such as; personal tendencies (curiosity and experimentation) among adolescent increased the risk to have SUD [1]. The environmental factors such as; lack of knowledge, peer pressure, imitating family members, family with uneducated mother, low academic achievement and absenteeism increase the risk to have adolescents with SUD.

\section{Conclusion}

The reviewed articles about the factors associated with SUD and their influences among adolescents have shown that there are different factors that influence adolescents to consume illegal substances. The factors are more likely to expose adolescents' to have SUD, like experiencing stressful life events such as death, loss of a job, anxiety, psychological aggression, painful memories like sexual abuse, depression are more likely to have SUD; adolescents try to escape from painful memories by consuming illegal substances. On the other hand, adolescents of educated mothers are less likely to have SUD because they educate their children about dangerous of illicit substances. Also, family support, strong attachment between children and parents, supervision by parents, pay attention and interest to children by their parents decrease the risk of adolescents to have SUD. At the same time, studies reported that adolescents are risker to have SUD because, in this developmental stage of adolescence, adolescents have personal tendencies like curiosity and experimentation to try any heath risk behaviors which is related to biological factors. Many of the revised articles questioned ways of adaptation and management for SUD in addition to the factors causes SUD, which means that less focusing on risk factors for SUD. The gaps were that some articles did not adequately highlight the process of occurring SUD by adolescents, did not adequately give clear examples how adolescents go to consume illegal substances after exposed to painful traumas or stress or any risk factors for SUD. Further studies are needed to address the role of the family in protecting adolescents from getting SUD and the other risk factors for SUD among adolescents as a specific age group. Less attention is given in the literature on the risk factors for SUD among adolescents. 


\section{Conflicts of Interest}

The authors state no conflicts of interest related to the publication of this paper.

\section{References}

[1] Berlowitz, I., Ghasarian, C., Walt, H., Mendive, F., Alvarado, V. and Martin-Soelch, C. (2018) Conceptions and Practices of an Integrative Treatment for Substance Use Disorders Involving Amazonian Medicine: Traditional Healers' Perspectives. Revista Brasileira de Psiquiatria, 40, 200-209. https://doi.org/10.1590/1516-4446-2016-2117

[2] Higgins, K., McLaughlin, A., Perra, O., McCartan, C., McCann, M., Percy, A. and Jordan, J.A. (2018) The Belfast Youth Development Study (BYDS): A Prospective Cohort Study of the Initiation, Persistence and Desistance of Substance Use from Adolescence to Adulthood in Northern Ireland. PLOS ONE, 13, e0195192. https://doi.org/10.1371/journal.pone.0195192

[3] National Institute on Drug Abuse (NIDA) (2019) Overdose Death Rates. Drugabuse.gov. https://www.drugabuse.gov/related-topics/trends-statistics/overdose-death-rates

[4] World Health Organization (2017) Substance Abuse. https://www.who.int/topics/substance_abuse/en/

[5] American Psychiatric Association (2013) Diagnostic and Statistical Manual of Mental Disorders. 5th Edition, American Psychiatric Association, Washington DC. https://doi.org/10.1176/appi.books.9780890425596

[6] Kapur, S. (2015) Adolescence: The Stage of Transition.

[7] Sanders, M.G. (2013) Schooling Students Placed at Risk: Research, Policy, and Practice in the Education of Poor and Minority Adolescents. Routledge, London. https://doi.org/10.4324/9781410605597

[8] Morris, S.L. (2007) Adolescent Substance Use: Developmental Considerations.

[9] Lisdahl, K.M., Sher, K.J., Conway, K.P., Gonzalez, R., Ewing, S.W.F., Nixon, S.J., Heitzeg, M., et al. (2018) Adolescent Brain Cognitive Development (ABCD) Study: Overview of Substance Use Assessment Methods. Developmental Cognitive Neuroscience, 32, 80-96. https://doi.org/10.1016/j.dcn.2018.02.007

[10] Chadi, N., Bagley, S.M. and Hadland, S.E. (2018) Addressing Adolescents' and Young Adults' Substance Use Disorders. Medical Clinics of North America, 102, 603-620. https://doi.org/10.1016/j.mcna.2018.02.015

[11] Sharma, A. and Morrow, J.D. (2016) Neurobiology of Adolescent Substance Use Disorders. Child and Adolescent Psychiatric Clinics, 25, 367-375.

https://doi.org/10.1016/j.chc.2016.02.001

[12] Erikson, E. (1950) Childhood and Society. WW Norton, New York.

[13] Beckson, M. (2005) Introduction to Special Section: Adolescent Substance Use and Addiction. Adolescent Psychiatry, 29, 3.

[14] Lalayants, M. and Prince, J.D. (2016) Child Neglect and Onset of Substance Use Disorders among Child Welfare-Involved Adolescents. Child Abuse Review, 25, 469-478. https://doi.org/10.1002/car.2372

[15] Dowd, K., Dolan, M., Wallin, J., Miller, K., Biemer, P., Aragon-Logan, E. and Smith, K. (2014) National Survey of Child and Adolescent Well-Being II (NSCAW II) Combined Waves 1-2, Data File User's Manual, Restricted Release Version. Cornell University, National Data Archive on Child Abuse and Neglect, Ithaca, New York. 
[16] Ali, M.M., Dean Jr., D. and Hedden, S.L. (2016) The Relationship between Parental Mental Illness and/or Substance Use Disorder on Adolescent Substance Use Disorder: Results from a Nationally Representative Survey. Addictive Behaviors, 59, 35-41. https://doi.org/10.1016/j.addbeh.2016.03.019

[17] Yitayih, Y., Abera, M., Tesfaye, E., Mamaru, A., Soboka, M. and Adorjan, K. (2018) Substance Use Disorder and Associated Factors among Prisoners in a Correctional Institution in Jimma, Southwest Ethiopia: A Cross-Sectional Study. BMC Psychiatry, 18, 314. https://doi.org/10.1186/s12888-018-1901-x

[18] Yoon, S., Pei, F., Wang, X., Yoon, D., Lee, G., McCarthy, K.S. and Schoppe-Sullivan, S.J. (2018) Vulnerability or Resilience to Early Substance Use among Adolescents at Risk: The Roles of Maltreatment and Father Involvement. Child Abuse \& Neglect, 86, 206-216. https://doi.org/10.1016/j.chiabu.2018.09.020

[19] Davis, J.P., Dworkin, E.R., Helton, J., Prindle, J., Patel, S., Dumas, T.M. and Miller, S. (2019) Extending Poly-Victimization Theory: Differential Effects of Adolescents' Experiences of Victimization on Substance Use Disorder Diagnoses upon Treatment Entry. Child Abuse \& Neglect, 89, 165-177. https://doi.org/10.1016/j.chiabu.2019.01.009

[20] Iranpour, A., Jamshidi, E., Nakhaee, N., Haghdoost, A.A., Shojaeizadeh, D., Eftekhar-Ardabili, M., et al. (2015) Development and Psychometric Properties of Risk and Protective Factors of Substance Use Scale in Iran: An Application of Social Development Model. Addiction and Health, 7, 117-129.

[21] Mason, W.A., Toumbourou, J.W., Herrenkohl, T.I., Hemphill, S.A., Catalano, R.F. and Patton, G.C. (2011) Early Age Alcohol Use and Later Alcohol Problems in Adolescents: Individual and Peer Mediators in a Bi-National Study. Psychology of Addictive Behaviors, 25, 625. https://doi.org/10.1037/a0023320

[22] Köck, P. and Walter, M. (2018) Personality Disorder and Substance Use Disorder-An Update. Mental Health \& Prevention, 12, 82-89. https://doi.org/10.1016/j.mhp.2018.10.003

[23] El Kazdouh, H., El-Ammari, A., Bouftini, S., El Fakir, S. and El Achhab, Y. (2018) Adolescents, Parents and Teachers' Perceptions of Risk and Protective Factors of Substance Use in Moroccan Adolescents: A Qualitative Study. Substance Abuse Treatment, Prevention, and Policy, 13, 31.

https://doi.org/10.1186/s13011-018-0169-y 


\section{Appendix}

\begin{tabular}{|c|c|c|c|c|}
\hline Domain & Title & $\begin{array}{c}\text { Author/s } \\
\text { Year }\end{array}$ & $\begin{array}{l}\text { Research } \\
\text { Aim }\end{array}$ & Sample Siz \\
\hline Practice (1) & $\begin{array}{l}\text { Child Neglect and Onset } \\
\text { of Substance Use } \\
\text { Disorders among Child } \\
\text { Welfare-Involved } \\
\text { Adolescents }\end{array}$ & $\begin{array}{l}\text { Lalayants, \& } \\
\text { Prince (2016) }\end{array}$ & $\begin{array}{l}\text { to clarify the } \\
\text { relationship be- } \\
\text { tween child abuse } \\
\text { and substance } \\
\text { dependence } \\
\text { versus child } \\
\text { neglect and } \\
\text { substance } \\
\text { dependence }\end{array}$ & $\mathrm{n}=5872$ \\
\hline
\end{tabular}

\begin{tabular}{|c|c|c|c|c|c|c|}
\hline Practice (2) & $\begin{array}{l}\text { The relationship } \\
\text { between parental mental } \\
\text { illness and/or substance } \\
\text { use disorder on } \\
\text { adolescent substance use } \\
\text { disorder: Results from a } \\
\text { nationally representative } \\
\text { survey }\end{array}$ & $\begin{array}{l}\text { Ali, Dean Jr, } \\
\text { \& Hedden } \\
\text { (2016) } \\
\text { \& }\end{array}$ & $\begin{array}{l}\text { The aim of the } \\
\text { study is to exam if } \\
\text { parents with } \\
\text { comorbid mental } \\
\text { illness and } \\
\text { substance use } \\
\text { disorder have } \\
\text { effects on their } \\
\text { adolescents and } \\
\text { be more risky to } \\
\text { have SUD }\end{array}$ & $\begin{array}{l}(\mathrm{n}=18,500) \\
\mathrm{f} \text { adolescents } \\
12-17 \text { years } \\
\text { old age } \\
(\mathrm{n}=9300) \\
\text { mother } \\
(\mathrm{n}=5300) \\
\text { father }\end{array}$ & $\begin{array}{l}\text { this data collected annually } \\
\text { using face to face interviews } \\
\text { from parents and their } \\
\text { children for the purpose of } \\
\text { detecting the prevalence and } \\
\text { correlates of substance use } \\
\text { and substance use disorders } \\
\text { among civilians in the United } \\
\text { States ages } 12 \text { years and above } \\
\text { considered a strength point } \\
\text { and the sample size was large } \\
\text { enough which considered } \\
\text { another strength point. }\end{array}$ & $\begin{array}{l}\text { Data analysis revealed two main } \\
\text { theme: } \\
\text { 1) Mothers have more influence than } \\
\text { fathers on their adolescents, so, } \\
\text { uneducated mothers are more risky to } \\
\text { have adolescents with SUD than } \\
\text { educated mothers. } \\
\text { 2) Mothers with SUD co morbid with } \\
\text { any mental illness are more risk to } \\
\text { have adoscents with SUD than } \\
\text { mothers with only SUD. }\end{array}$ \\
\hline Practice (3) & $\begin{array}{l}\text { Substance use disorder } \\
\text { and associated } \\
\text { factors among prisoners } \\
\text { in a correctional } \\
\text { institution in Jimma, } \\
\text { Southwest Ethiopia: a } \\
\text { cross-sectional study }\end{array}$ & $\begin{array}{l}\text { Yitayih et al. } \\
\text { (2018) }\end{array}$ & $\begin{array}{l}\text { to study the } \\
\text { prevalence of } \\
\text { SUD in Jimma } \\
\text { and associated } \\
\text { factors among } \\
\text { prisoners. }\end{array}$ & $\mathrm{n}=336$ & $\begin{array}{l}\text { Being in caring strategies or } \\
\text { interventions offered in } \\
\text { correctional institutions will } \\
\text { help to improve prisoners } \\
\text { health and decrease the } \\
\text { complications. }\end{array}$ & $\begin{array}{l}\text { Analysis revealed four themes: } \\
\text { 1) Lack of social support } \\
\text { 2) live in urban areas } \\
\text { 3) lack of supervision by parents } \\
\text { 4) and individuals with psychopath } \\
\text { illness are more likely to have SUD. }\end{array}$ \\
\hline Practice (4) & $\begin{array}{l}\text { Vulnerability or } \\
\text { resilience to early } \\
\text { substance use among } \\
\text { adolescents at risk: The } \\
\text { roles of maltreatment } \\
\text { and father } \\
\text { involvement }\end{array}$ & $\begin{array}{l}\text { Yoon et al. } \\
\text { (2018) }\end{array}$ & $\begin{array}{l}\text { This study aimed } \\
\text { to examine if } \\
\text { maltreatment in } \\
\text { early childhood } \\
0 \text { - } 5 \text { years and in } \\
\text { mid-late } \\
\text { childhood } 6 \text { - } 12 \\
\text { years develop } \\
\text { early substance } \\
\text { use among ado- } \\
\text { lescents. }\end{array}$ & $\begin{array}{l}\mathrm{n}=685 \\
\text { adolescents } \\
(12-14)\end{array}$ & $\begin{array}{l}\text { This study gave a clue foe } \\
\text { researchers to identify the } \\
\text { children needs and help to } \\
\text { develop a strategy to protect } \\
\text { children from becoming } \\
\text { substance users. In view of } \\
\text { the requirements for } \\
\text { information, it was verified } \\
\text { that health education allowed } \\
\text { parents to become aware of } \\
\text { their children needs and } \\
\text { aware how to protect them } \\
\text { from substances. }\end{array}$ & $\begin{array}{l}\text { Data Analysis revealed three main } \\
\text { themes: } \\
\text { 1) Lack of bonding between parents } \\
\text { and children in the early childhood } \\
\text { increase the risk to have adolescents } \\
\text { for substance use. } \\
\text { 1) Physical abuse during early } \\
\text { childhood period ( } 0 \text { - } 5 \text { years of age) } \\
\text { and mid-late childhood ( } 6 \text { - } 12 \text { years } \\
\text { of age) increase the risk of adolescents } \\
\text { for substance use than other children } \\
\text { who didn't experienced physical } \\
\text { abuse. } \\
\text { 3) Educated mothers are less likely to } \\
\text { have adolescents with substance use. }\end{array}$ \\
\hline Practice (5) & $\begin{array}{l}\text { Extending } \\
\text { poly-victimization } \\
\text { theory: differential } \\
\text { effects of adolescents' } \\
\text { experiences of } \\
\text { victimization on } \\
\text { substance use disorder } \\
\text { diagnoses upon } \\
\text { treatment entry }\end{array}$ & $\begin{array}{l}\text { Davis, J et al. } \\
\text { (2019) }\end{array}$ & $\begin{array}{l}\text { The aim of the } \\
\text { study is to assess } \\
\text { if there a } \\
\text { relationship } \\
\text { between } \\
\text { adolescents } \\
\text { victimization and } \\
\text { substance use } \\
\text { disorder }\end{array}$ & $\mathrm{n}=20,093$ & $\begin{array}{l}\text { The sample size is large } \\
\text { which considered a strength } \\
\text { point, the analytical process } \\
\text { take in consideration } \\
\text { multiple aspects of } \\
\text { victimization }\end{array}$ & $\begin{array}{l}\text { Data analysis revealed one main } \\
\text { theme: } \\
\text { 1) adolescents who experience } \\
\text { victimization more than two times are } \\
\text { more risk to have SUD or psychiatric } \\
\text { disorders. }\end{array}$ \\
\hline
\end{tabular}

Strength of The Findings Analysis \& Results

The data set containing many Analysis revealed four themes: information about social 1) Child and youth maltreatment relationship, services needs, increase the risk for SUD. mental health and academic 2) Negligence, psychological achievement for children and aggression, physical assault, sexual their caregivers and other abuse for children and youth increase many other important information which enabled researchers to deeply the risk for SUD. understand the risk factors of in order to forget undesirable 3) Painful memories, self blame and depression increase the risk for SUD SUD. memories.

The relationship Ali, Dean Jr, The aim of the $\quad(n=18,500)$ etween parental mental \& Hedden study is to exam if adolescents stance use nationally representative and associated

Yitayih et al. to study the factors amon prisoners. adolescen substance use among adolescents at risk: The and father involvement

Extending heory: differential experiences of victimization on diagnoses upon
The sample size is large take in consideration multiple aspects of victimization 


\section{Continued}

\begin{tabular}{|c|c|c|c|c|c|c|}
\hline Practice (6) & $\begin{array}{l}\text { Conceptions and } \\
\text { practices of an } \\
\text { integrative treatment for } \\
\text { substance use disorders } \\
\text { involving Amazonian } \\
\text { medicine: traditional } \\
\text { healers' perspectives }\end{array}$ & $\begin{array}{l}\text { Berlowitz et } \\
\text { al. (2018) }\end{array}$ & $\begin{array}{l}\text { To investigate } \\
\text { alternative } \\
\text { treatments from } \\
\text { traditional } \\
\text { Amazonian } \\
\text { medicine adapted } \\
\text { to SUDs }\end{array}$ & & $\begin{array}{l}\text { This study has provided } \\
\text { insight into the experiences } \\
\text { of biomedical practitioners } \\
\text { and biomedical experts and } \\
\text { their cooperation will aid to } \\
\text { develop a good treatment } \\
\text { strategy for individuals with } \\
\text { substance use disorder. }\end{array}$ & $\begin{array}{l}\text { Data analysis revealed three themes: } \\
\text { psychosocial factors like stress life } \\
\text { events, anxiety. Socio-cultural factors } \\
\text { like low self esteem, loneliness and } \\
\text { lack of attachment with family. } \\
\text { Biological factors like personal } \\
\text { tendencies (curiosity and } \\
\text { experimentation). }\end{array}$ \\
\hline Practice (7) & $\begin{array}{l}\text { Development and } \\
\text { Psychometric Properties } \\
\text { of Risk and Protective } \\
\text { Factors of Substance } \\
\text { Use Scale in Iran: An } \\
\text { Application of Social } \\
\text { Development Model }\end{array}$ & $\begin{array}{l}\text { Iranpour et } \\
\text { al. (2015) }\end{array}$ & $\begin{array}{l}\text { This study aimed } \\
\text { to create } \\
\text { protective factors } \\
\text { for SUD based on } \\
\text { Social } \\
\text { Development } \\
\text { Model. }\end{array}$ & $\begin{array}{l}(\mathrm{n}=325) \\
14-18 \text { years } \\
\text { old }\end{array}$ & $\begin{array}{l}\text { An explanatory student } \\
\text { journey model demonstrated } \\
\text { that developing self-efficacy } \\
\text { was key to their successful } \\
\text { transition through the first } \\
\text { year of undergraduate study. }\end{array}$ & $\begin{array}{l}\text { Analysis revealed four themes: } \\
\text { 1) Wrong thoughts about some illicit } \\
\text { drugs. For example: they believe that } \\
\text { hookah and alcohol do not have } \\
\text { negative consequences like other illicit } \\
\text { substances. } \\
\text { 2) Lack of parental supervision which } \\
\text { can increase the risk to have SUD. } \\
\text { 3) Lack of bonding and attachments } \\
\text { with parents increase the tendency of } \\
\text { adolescents to have SUD. } \\
\text { 4) inappropriate relationship between } \\
\text { family and adolescents increase the } \\
\text { tendency of adolescents to have risk } \\
\text { health behaviors like SUD }\end{array}$ \\
\hline Practice (8) & $\begin{array}{l}\text { Early-Age Alcohol Use } \\
\text { and Later Alcohol } \\
\text { Problems in } \\
\text { Adolescents: Individual } \\
\text { and Peer Mediators in a } \\
\text { Bi-National } \\
\text { Study }\end{array}$ & $\begin{array}{l}\text { Mason et al. } \\
(2011)\end{array}$ & $\begin{array}{l}\text { To examine if } \\
\text { there is a } \\
\text { relationship } \\
\text { between early age } \\
\text { alcohol use and } \\
\text { adolescents } \\
\text { alcohol problems. }\end{array}$ & $\begin{array}{l}\mathrm{n}=1945 \\
(14-16 \text { years } \\
\text { old }) \\
\end{array}$ & $\begin{array}{l}\text { The preceptor ship of new } \\
\text { nurses is challenging and } \\
\text { stressful. Preceptors endure } \\
\text { several roles concurrently, } \\
\text { thus, their workload should } \\
\text { be balanced appropriately in } \\
\text { order not to compromise } \\
\text { with one another and evade } \\
\text { burnout }\end{array}$ & $\begin{array}{l}\text { Data Analysis revealed one main } \\
\text { theme: } \\
\text { 1) Poor self regulation and peer } \\
\text { aberration increase the tendency of } \\
\text { adolescents for alcohol abuse. }\end{array}$ \\
\hline Practice (9) & $\begin{array}{l}\text { Adolescents, parents } \\
\text { and teachers' } \\
\text { perceptions of risk and } \\
\text { protective factors of } \\
\text { substance use in } \\
\text { Moroccan adolescents: a } \\
\text { qualitative study }\end{array}$ & $\begin{array}{l}\text { Elkazdouh et } \\
\text { al. (2018) }\end{array}$ & $\begin{array}{l}\text { The study aimed } \\
\text { to understand } \\
\text { factors that } \\
\text { influence } \\
\text { morocco } \\
\text { adolescents to } \\
\text { consume illicit } \\
\text { substances } \\
\text { through explore } \\
\text { the perceptions of } \\
\text { students and their } \\
\text { parents and } \\
\text { teachers }\end{array}$ & $\begin{array}{l}\mathrm{n}=56 \\
\text { adolescents } \\
14-16 \text { years } \\
\text { And } \\
\mathrm{N}=26 \text { parents } \\
\text { males and } \\
\text { females }\end{array}$ & $\begin{array}{l}\text { This study used qualitative } \\
\text { approach which allow for } \\
\text { researchers to deeply } \\
\text { understand adolescents } \\
\text { perception toward illicit } \\
\text { substances and another } \\
\text { helping factor in detecting } \\
\text { factors that influence } \\
\text { adolescents to consume illicit } \\
\text { substances is the interview of } \\
\text { adolescents' parents. }\end{array}$ & $\begin{array}{l}\text { Data analysis revealed six main } \\
\text { themes: } \\
\text { 1) Distorted thoughts that they can } \\
\text { forget painful experiences by taking } \\
\text { illicit substance. } \\
\text { 2) Misunderstanding the } \\
\text { complications of these substances, } \\
\text { they lack knowledge about serious } \\
\text { complications on the body. } \\
\text { 3) Lack of supervision by parents. } \\
\text { 4) Peer pressure and imitating family } \\
\text { members } \\
\text { 5) Adolescents with any mental illness } \\
\text { like personality disorder are at high } \\
\text { risk for consuming substances. } \\
\text { 6) Absenteeism and low academic } \\
\text { achievement increase the risk to make } \\
\text { relationship with deviants. }\end{array}$ \\
\hline
\end{tabular}

